Research article

\title{
GLEANING A HUMAN DNA PROFILE FROM TRACE SWABS COLLECTED FROM ANIMAL HAIRS
}

\author{
ŠPOLJARIĆ Branimira ${ }^{1}$, POPOVIĆ Maja ${ }^{1}$, CRNJAC Josip ${ }^{2}$, ŽDERIĆ SAVATOVIĆ \\ Zrinka ${ }^{3}$, RATKO Martina ${ }^{4}$, LOZANČIĆ Mateja ${ }^{4}$, JURAK Matea ${ }^{5}$, ŠPOLJARIĆ Igor ${ }^{4}$, \\ ŠPOLJARIĆ Daniel ${ }^{1}$, MRŠIĆ Gordan**
}

${ }^{1}$ Faculty of Veterinary Medicine, University of Zagreb, Zagreb, Croatia; ${ }^{2}$ University Department for Forensic Sciences, University of Split, Split, Croatia; ${ }^{3}$ Student of doctoral study of veterinary sciences of Faculty of Veterinary Medicine, University of Zagreb, Zagreb, Croatia; ${ }^{4}$ Forensic Science Centre „Ivan Vučetićc", General Police Directorate, Ministry of Interior, Zagreb, Croatia; ${ }^{5}$ Student of integrated undergraduate and graduate studies of Faculty of Veterinary Medicine, University of Zagreb, Zagreb, Croatia

(Received 24 August 2015; Accepted 26 February 2016)

Animal hairs are an apt surface for retention of forensic trace epithelial samples. The aim of this study was threefold: to evaluate different methods of sample collection (moistened and dry swabs) and DNA extraction (Chelex ${ }^{\circledR} 100$ method, Qiagen EZ1 ${ }^{\circledR}$ DNA Investigator Kit), as well as to examine the morphological differences of hair fibres between two species (dog, sheep) and their ultimate impact on sample collection and processing. Our preliminary findings suggest that the use of EZ1 ${ }^{\circledR}$ DNA Investigator Kit yields donor DNA profiles of higher quality. The results of different sample collection methods have shown intraspecific variations that require further investigation. The ability of retention and subsequent extraction of trace DNA appears to be similar between the two species, despite significant morphological differences between their coat hairs.

Keywords: DNA profiling, sheep wool, dog hair, Chelex ${ }^{\circledR} 100$, Qiagen EZ1 ${ }^{\circledR}$ DNA Investigator Kit

\section{INTRODUCTION}

Locard's exchange principle states that „Every contact leaves a trace“, though that trace material needs not be visible to the observer's naked eye. Biological trace materials may be of either human, plant or animal origin, and are crucial in understanding a crime scene, individuals involved and the course of events that took place. Their value became evident with the discovery of DNA fingerprinting methods, which enabled individualisation of collected samples and proving sample origin with a high degree of reliability. The key component needed for DNA fingerprinting to work is the presence

\footnotetext{
*Corresponding author: e-mail: gmrsic@mup.hr
} 
of nucleated cells, found in a wide array of bodily fluids (blood, saliva, semen), body hair and shed epithelial cells [1]. Trace evidence may be deposited on a surface, animal or human being by several methods. One of these methods includes direct deposition, where there is a direct contact between the source and the carrier [2].

Animals are a part of most people's daily lives, they are kept as pets or are bred for economic purposes (food, clothing materials, husbandry). In either role, they are in frequent contact with their human handlers, and trace material is often transferred. Their ability to retain trace evidence from their surrounding becomes more relevant if they are involved with a criminal investigation. There are three ways in which an animal may be involved in a criminal case - as a victim, perpetrator or witness. Regardless of the method of involvement, their bodies may retain key clues, which can connect individuals involved with the crime to each other, the animal, or the crime scene itself [3]. An animal's body is densely covered with fur, which enables retention of a wide variety of trace evidence (hair, fiber, pollen, powders, epithelial cells, bodily fluids, etc.); however, the same fact hampers evidence detection.

The aim of this preliminary research was to investigate the possibility and successfulness of collecting human trace DNA evidence off animal hair. Two test subjects were chosen, one a pet species (dog) and the other a species of economical importance (sheep).

One way in which a dog may be immersed in a criminal act is animal fighting. Dog breeds, such as pit bull terriers or the Presa Canario breed, are mainly used for such purposes. These animals are in continuous physical contact with their handlers during training, as well as dog fight organisers who are often required to restrain them throughout the fights. Such physical contact will almost certainly lead to mutual exchange of trace matter, such as saliva or epithelial cells [4].

Sheep are most commonly used for the production of wool and mutton, as well as milk production to a lesser degree. Many breeds exist of varying qualities. A breed indigenous to Croatia, called Lika pramenka, was chosen as the test subject. It can be used for all three purposes listed previously, and is the most common breed of sheep economically exploited in Croatia. Because of their economical importance, sheep rustling and theft is an ongoing problem.

DNA extraction from trace evidence is a precarious procedure due to a limited amount of DNA available for detection and analysis. Two DNA extraction methods were used in this study in order to test their efficiency with this type of trace evidence.

The Chelex ${ }^{\circledR} 100$ DNA extraction method utilizes a chelating agent with an affinity for magnesium cations. The removal of $\mathrm{Mg}^{2+}$ ions in an alkaline medium causes nuclease deactivation, an important step in protecting DNA from degradation. Another ingredient used in this method is Proteinase $\mathrm{K}$ which degrades proteins. After sample incubation, single-stranded DNA molecules are left in the supernatant [5].

Another DNA extraction method involves the use of EZ1® DNA Investigator Kit. The method consists of two steps, where DNA extraction by means of proteinase K 
digestion is a pretreatment step, after which genomic DNA undergoes a purification protocol. This method is applicable to a wide variety of forensic samples, with individual pretreatment protocols for each one for optimal results [6]. Purification is carried out with magnetic particles and a series of wash and elution buffers. The purification part of his procedure may give it an advantage over the Chelex ${ }^{\circledR}$ method, where DNA is solely released into a medium, along with other organic and inorganic matter.

\section{MATERIALS AND METHODS}

\section{Biological samples}

Biological reference samples were taken in the DNA laboratory of the Department of biology and fibers of the Forensic Science Centre „Ivan Vučetic“, Zagreb, Croatia. Buccal swab samples were collected with the use of sterile swabs (Whatman ${ }^{\circledR}$ OmniSwab) from three donors, two males (D1 and D2) and a female (D3), for the purpose of determining their reference DNA profiles. The samples were allowed to air-dry before further processing.

Animal hairs were sampled from the interscapular area (regio interscapularis) of eight animals belonging to two species - four sheep from a Croatian breed „Lika pramenka“ and four dogs of mixed breeds. Hair samples were collected with a cutting knife, packed separately in paper envelopes and delivered to the DNA laboratory. Sheep were obtained from the Reproduction and Obstetrics Clinic of the Faculty of Veterinary Medicine, Zagreb, Croatia; dog hairs were sampled after owner permission was given. This research was given ethical approval by the Ethics committee of the Faculty of Veterinary Medicine.

\section{Electron microscopy of hair samples}

For visualisation and analysis of animal hair morphology two devices were used: comparison microscope LEICA FS CB - DM 2500 (LEICA DFC-295 camera, LEICA LAS Core V3 microscope imaging software) and scanning electrone microscope (MIRA3 LM TESCAN). Hair samples from both species were cleaned with sterile cotton pads dipped in ethanol $(20 \%$, Kemika, Croatia) immediately before imaging. Samples were imaged again after human epithelial cells from one of the donors were deposited on the hair surface.

\section{Trace DNA collection}

Upon delivery to the DNA laboratory, hair samples from each of the eight animals were divided into four groups (one control and three test groups, i.e. a total of eight control and 24 test groups). Two dry and two moistened swabs were collected for each sample of animal hairs using sterile cotton swabs (Sarstedt, Germany), numbering 32 control samples in total. 
Each of the three donors was instructed to rub one hair sample of each animal between their fingers for ten seconds, with the purpose of depositing their epithelial cells on the hair surface. Four swabs were collected for each sample of each donor two dry swabs (dry sterile cotton swabs, Sarstedt, Germany) and two moistened swabs (ultrafiltered water added to sterile cotton swabs). In between sample collections, hair samples were rubbed anew. The result was 96 trace samples, 48 collected with dry swabs and 48 collected with moistened swabs.

\section{Methods of DNA isolation and quantification}

DNA from control samples (32) was extracted with the use of the Chelex ${ }^{\circledR} 100$ resin (Internal validated protocol for isolation of DNA from epithelial cells, RU-113/14, 30.12.2014.). The isolated DNA from control samples was then quantified with rRT-PCR and the use of Quantifiler ${ }^{\circledR}$ Human DNA Quantification Kit (Applied Biosystems, 2006) (Internal validated protocol for DNA quantification, RU-113/1-12, 15.12.2014.).

Trace DNA samples collected from animal hair (96) were separated evenly into two test groups, A and B, where each group containted one dry and one moistened swab from each animal handled by each donor. Trace samples in test group A (48) underwent an inorganic DNA isolation procedure with the use od Chelex ${ }^{\circledR} 100$ reagent $(5 \%$ Chelex solution), according to an internal validated protocol for isolation of DNA from epithelial cells, RU-113/1-4, 30.12.2014. DNA from trace samples in test group B (48) was isolated with the use of $\mathrm{EZ1} 1^{\circledR}$ DNA Investigator Kit (Qiagen) for DNA isolation on EZ1 ${ }^{\circledR}$ Advanced XL (Qiagen) device, according to manufacturer's instructions. DNA quantification was performed by qRT-PCR method with the use of Quantifiler ${ }^{\circledR}$ Human DNA Quantification Kit (Applied Biosystems, 2006) for samples from both test groups (Internal validated protocol for DNA quantification, RU-113/1-12, 15.12.2014.).

\section{DNA fragment amplification, detection and analysis}

DNA isolated from control and epithelial trace samples of both test groups, along with DNA from the reference donor samples, was amplified with the use of AmpFISTR ${ }^{\circledR}$ $\mathrm{NGM}^{\mathrm{TM}}$ PCR amplification kit (Applied Biosystems, USA) according to an internal validated protocol for DNA amplification, RU-113/1-13, 30.12.2014., on GeneAmp ${ }^{\circledR}$ PCR System 9700 (Applied Biosystems, USA) thermocycler. AmpFISTR ${ }^{\circledR}$ NGM $^{\mathrm{TM}}$ PCR amplification kit amplifies 15 human STR loci (D10S1248, vWA, D16S539, D2S1338, D8S1179, D21S11, D18S51, D22S1045, D19S433, TH01, FGA, D2S441, D3S1358, D1S1656, D12S391) as well as the amelogenin locus.

Fluorescently labelled DNA fragments from trace samples of test and control groups were separated by capillary electrophoresis on 3500 Genetic Analyzer (Applied Biosystems) device (Internal validated protocol for capillary electrophoresis, RU113/1-14, 15.01.2015). The results were then analyzed with GeneMapper ID-X ver. 
1.4, with minimum peak height of 75 RFUs (relative fluorescence units). Reference donor samples were subjected to the same procedure, except the minimum peak height was set to 150 RFUs due to higher expected DNA concentrations in reference samples.

Trace DNA samples were compared with reference DNA samples, in order to rule out nul alleles, allele drop-out or drop-in, and to determine the success of either method for DNA collection and isolation.

\section{RESULTS}

\section{Animal hair microscopy}

Dog and sheep hair samples were first visualised with the use of comparison microscope LEICA FS CB - DM 2500. Dog hairs possessed a thin and smooth, colorless outer layer (cuticle), with a darker continuous core (medulla) composed of nearly identical air chambers (Fig. 1A). Pigment granules could be found nearer to the medulla. Sheep hair had a narrower diameter than dog hairs, and did not contain a visible medulla or pigment granules throughout the hair shaft. The cuticle was wider and appeared ridged (Fig. 1B).
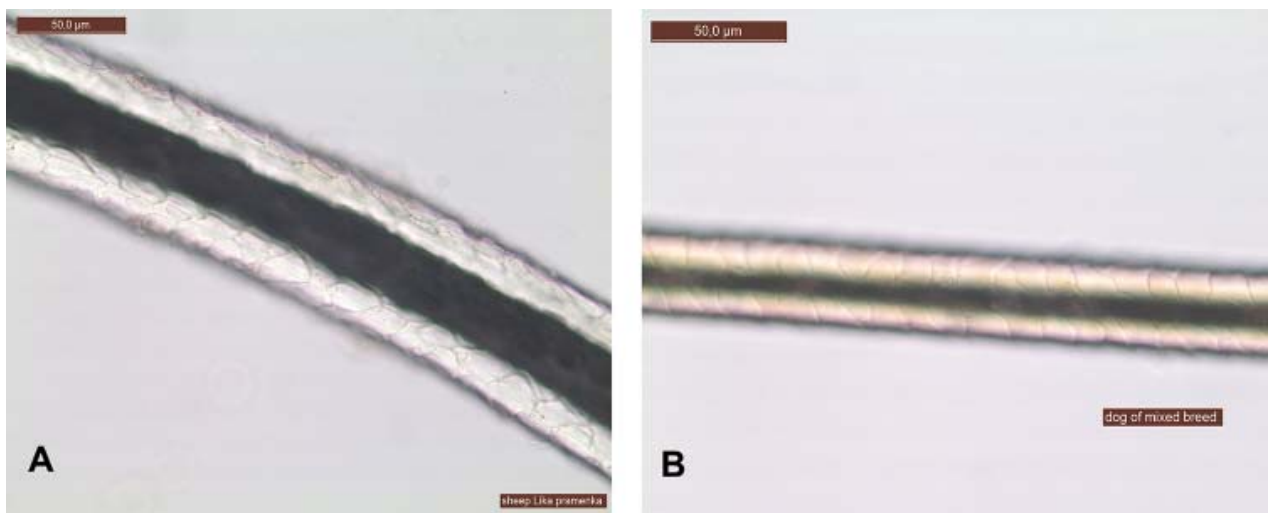

Figure 1. Sheep (A) and $\operatorname{dog}$ (B) coat hairs visualised through the use of comparison microscope LEICA FS CB - DM 2500

Hair samples were then viewed under an electron microscope for the purpose of visualizing the ultrastructure of hair shafts and scale patterns, as well as epithelial cells retained on the hair after they were rubbed by a donor. Dog hair had elongated and regular-shaped scales; they were inconspicuous and made the hair shaft appear smooth, similar to the bark of a larch tree. The smoothness of the hair surface enabled only a small number of donor epithelial cells to adhere to its surface (Fig. 2A). On the other hand, the sheep hair cuticle was comprised of ellipsoidal keratin scales with raised and sharp edges. Scales were 3-4 $\mu \mathrm{m}$ in diameter and densely packed, making the cuticle 
surface course and barbed, unlike the cuticle surface of dog hairs. Significantly more epithelial cells were visible covering the sheep hair shaft than dog hair shafts (Fig. 2B).
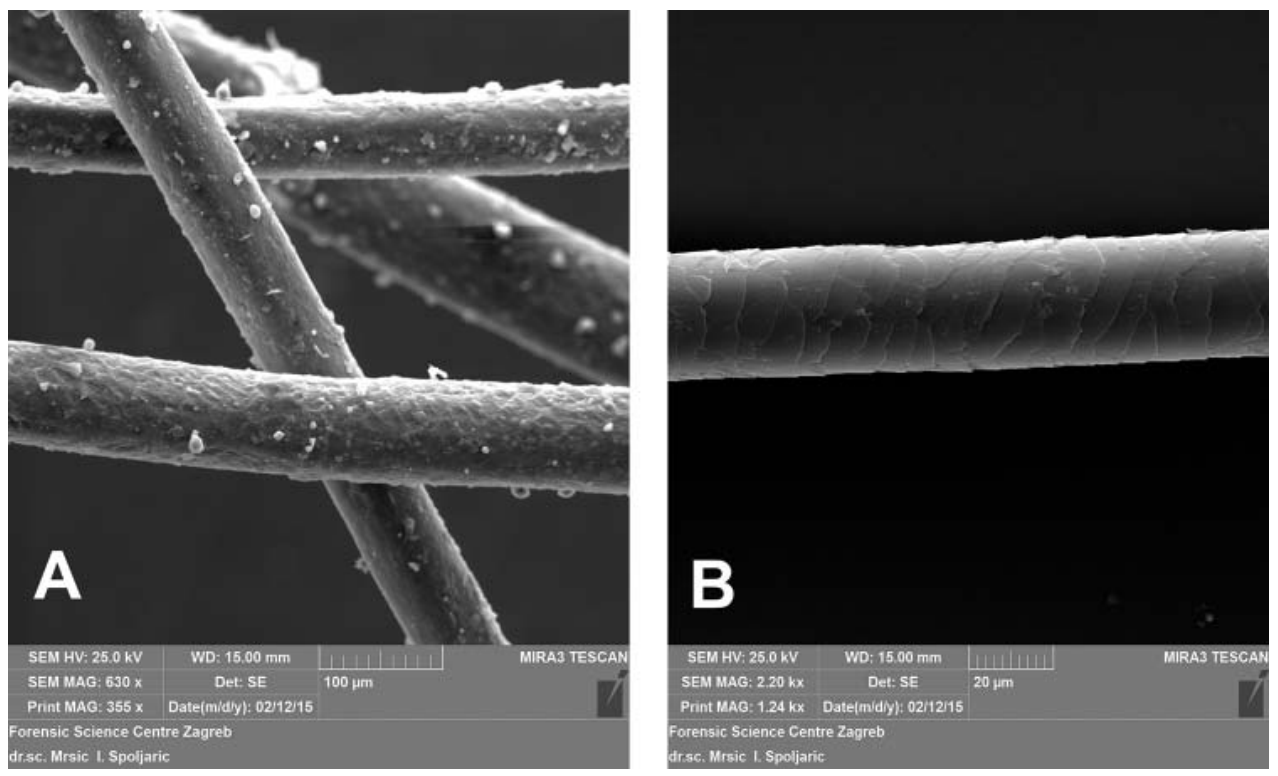

Figure 2. Scanning electron microscope MIRA3 LM TESCAN was used to image dog and sheep coat hairs prior and after deposition of donor DNA samples. Fig. 2A shows sheep hair surface after deposition with retained donor epithelial cells. Fig. 2B shows dog hair surface prior to deposition.

\section{Epithelial trace swab analysis}

Reference samples underwent an inorganic extraction method (5\% Chelex ${ }^{\circledR}$ reagent) and full DNA profiles were obtained for all three donors at predetermined peak heights of 150 RFUs. These results were later on compared with forensic trace swab results in order to rule out allele drop-in or drop-out, null alleles or possible contamination during sampling and extraction.

Contamination of hair samples prior to deposition of epithelial cells by donors was ruled out by the use of a control group. Control swabs underwent an inorganic extraction protocol identical to the one for reference samples $\left(5 \%\right.$ Chelex $^{\circledR}$ reagent), except the minimal allele peak height was set at 75 RFUs, similar to that of forensic samples. The results of both dry and moistened control swabs showed no prior contamination of hair samples, and so it was ruled they were fit to be used in the next step of the experiment.

Epithelial trace samples obtained from dry and moistened swabs of two animal species (dog and sheep) underwent two methods of DNA extraction. DNA from half the samples (48) was extracted with EZ1 ${ }^{\circledR}$ DNA Investigator Kit (Qiagen) for DNA 
isolation on $\mathrm{EZ1} 1^{\circledR}$ Advanced XL (Qiagen) device, while the other half underwent and inorganic extraction protocol ( $5 \% \mathrm{Chelex}^{\circledR}$ reagent). DNA profiles obtained from both methods of sampling and extraction were subsequently analysed and compared with reference DNA profiles of all three donors. Each examined locus was marked as either a blank (no alleles detected), partial (P, one of two possible alleles was detected) or full locus profile (F, all possible alleles for that locus were detected), and the results are represented in Tables 1 - 4. Heterozygous loci with disproportionate peak heights were omitted from further analysis, i.e. were marked as blank profiles. A summary of research results is depicted in Table 5 .

The EZ $1{ }^{\circledR}$ DNA Investigator Kit showed to be a more reliable method for DNA extraction from epithelial trace samples. A greater number of full locus profiles was obtained through its use, and consequently there were fewer instances of allele dropout. Two full donor profiles were obtained (both from sheep hair samples), along with four partial donor profiles which contained only one partial locus profile (i.e. one allele missing from the entire donor profile) (Tables 1 and 2). Contrary to this, more instances of allelic drop-out and notably fewer full locus profiles were detected in samples where DNA was extracted with the Chelex ${ }^{\circledR}$ reagent (Tables 3 and 4). The EZ1 ${ }^{\circledR}$ DNA Investigator Kit clearly outperformed the Chelex ${ }^{\circledR}$ reagent on trace swabs collected from sheep hair samples; however, the difference was less marked for trace swabs collected from dog hair samples.

Results of the comparison of two sampling methods were less uniform. The moistened swab method showed a distinct advantage when applied to dog hair samples (Tables 1 and 3), significantly increasing allele detection over the dry swab method. For sheep hair samples the difference between the two methods was decidedly less notable, and the dry swab method showed to be somewhat more efficient than the moistened swab method (Tables 2 and 4).

A slight discrepancy was also noted between the successfulness of DNA extraction from trace epithelial cells deposited on dog hair samples to those deposited on sheep hair samples. Dog hairs appear to be a moderately more apt trace carrier, enabling the extraction and subsequent detection of a larger number of alleles. Interestingly, the only two full donor profiles obtained were sampled and extracted from sheep hair samples. 


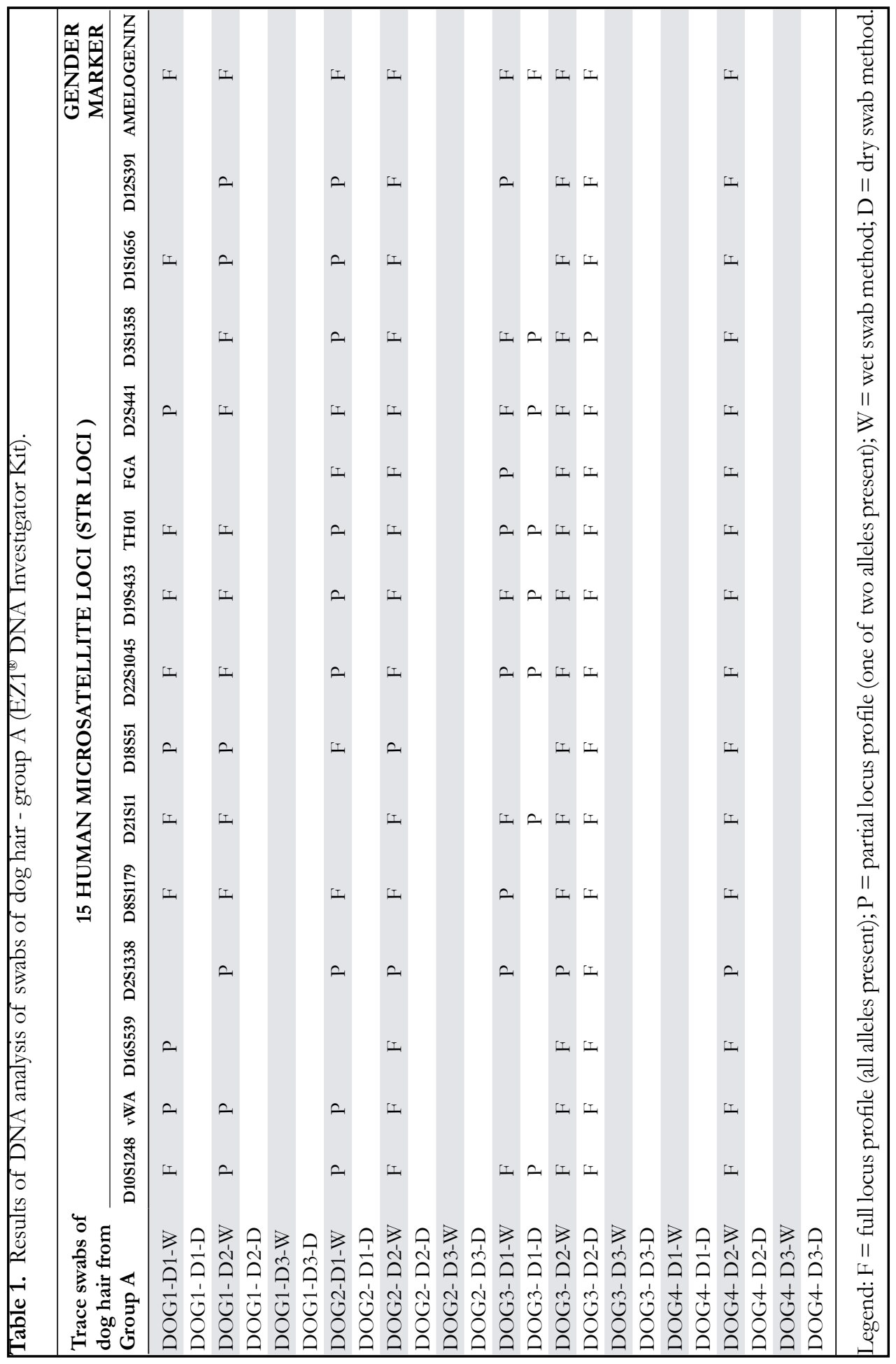




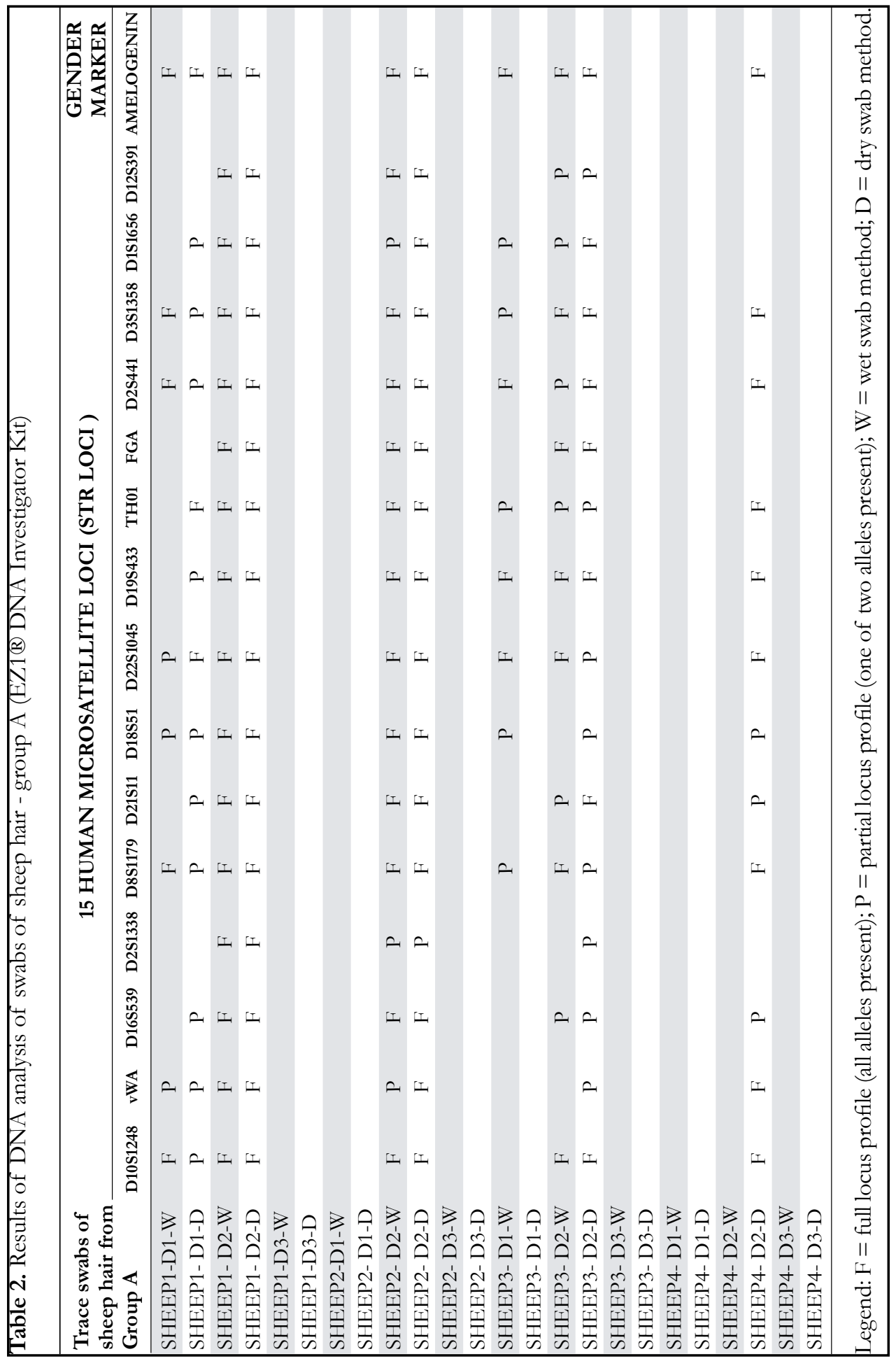




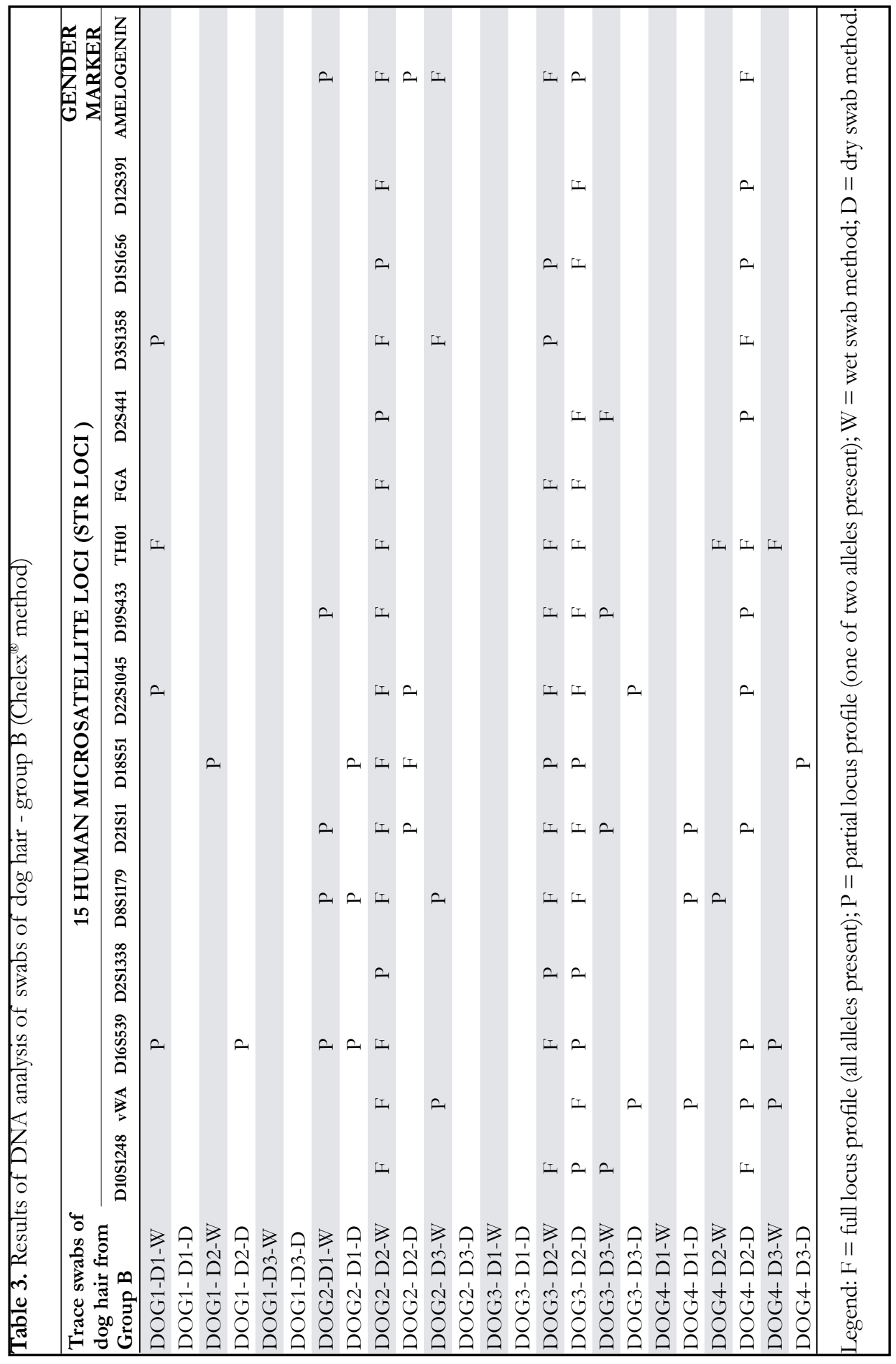




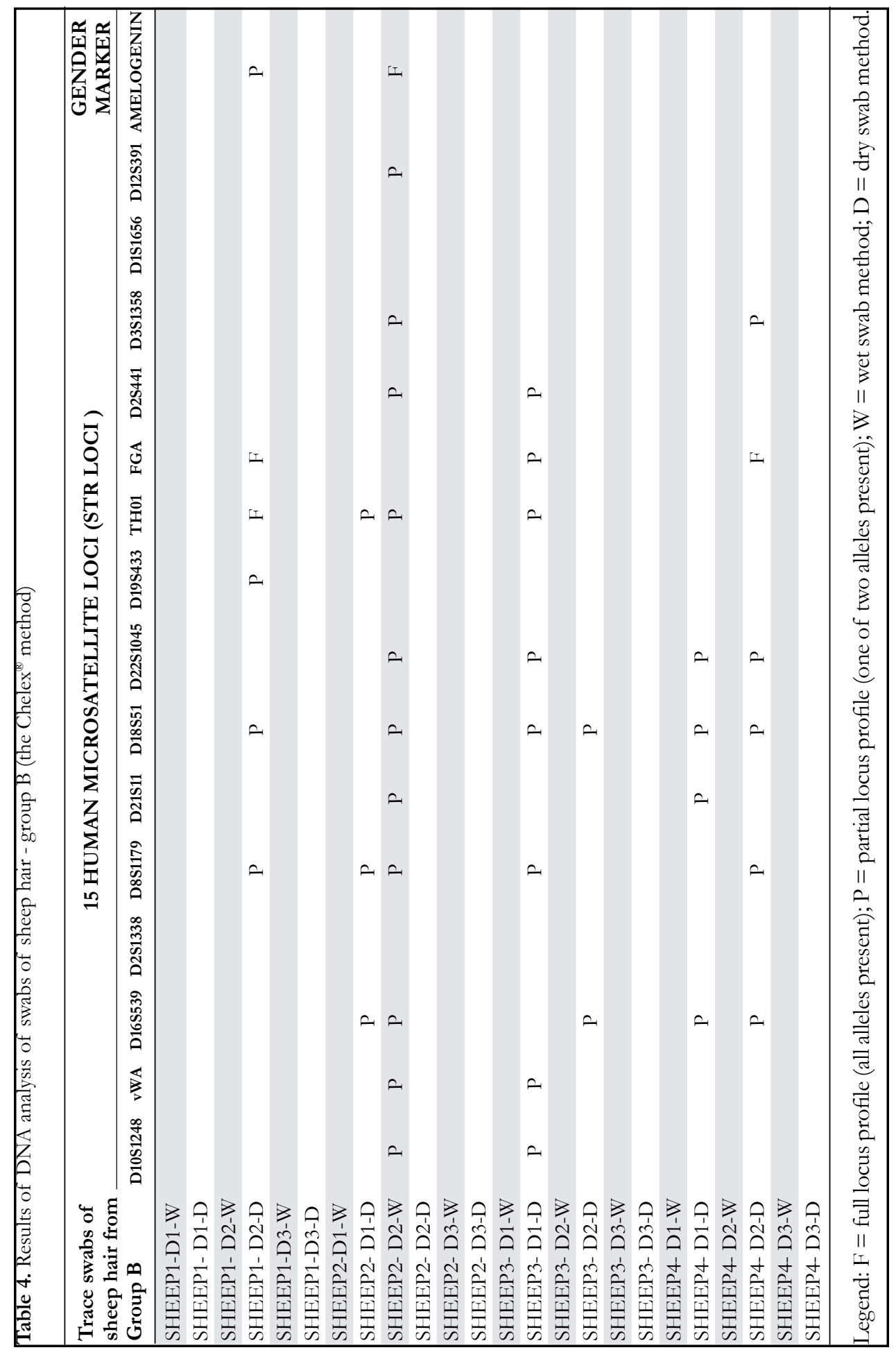


Table 5. Summary results of DNA analysis for both sampling and extraction methods

\begin{tabular}{lcccc}
\hline & & Partial locus profiles & Full locus profiles \\
\hline \multirow{3}{*}{$\begin{array}{l}\text { EZ1® DNA } \\
\text { Investigator Kit }\end{array}$} & Dog & Wet swab & 29 & 71 \\
& & Dry swab & 8 & 16 \\
& Sheep & Wet swab & 17 & 45 \\
& & Dry swab & 22 & 51 \\
& \multirow{2}{*}{ Dog } & Wet swab & 24 & 28 \\
Chelex® 100 & & Dry swab & 26 & 15 \\
& \multirow{3}{*}{ Sheep } & Wet swab & 11 & 1 \\
& & Dry swab & 26 & 3 \\
\hline
\end{tabular}

\section{DISCUSSION}

The key hair feature of interest for this study was the hair shaft surface. The cuticle is made up of flattened, keratinized cells of varying shapes, which exclusively point towards the distal end of the hair shaft and form distinct scale patterns. Said scale patterns cannot be used for individualisation, but they contribute to species identification in forensic examinations. In such instances, cuticular scales can either be viewed directly with a scanning electron microscope, or a cast can be made of the scale patterns and subsequently examined under a light microscope [7]. When viewed under a scanning electron microscope, sheep cuticular scales protrude significantly out of the hair shaft, thus creating a jagged landscape which should be capable of ensnaring sloughed donor epithelial cells. Dog cuticular scales, on the other hand, are laid flat along the hair shaft and create a smooth, nonporous surface. Research conducted so far has had contradictory results regarding which characteristics of carriers would be most beneficial to trace DNA retention. One research showed rough substrates to be ideal for trace DNA recovery [8], from which it would follow that the jagged sheep hair surface would better retain donor epithelial cells. As a point of fact, the only two full donor profiles obtained in this study were retrieved from sheep hair swabs. Another research showed smooth nonporous surfaces to be more efficient trace DNA carriers, attributing it to the fixation of trace DNA with sweat deposited simultaneously with donor epithelial cells [9]. Results of DNA extraction from swabs collected from both species showed an unexpectedly similar success rate, with marginally more successful results for swabs collected off dog hairs. Further research is needed to pinpoint the favourable characteristics of carrier surface for the retention of human epithelial cells. 
The aim of the study was to determine which DNA extraction method would work best with a certain type of trace samples, namely swabs of human epithelial cells lifted from animal hairs. In the past several decades, many studies were conducted in order to identify polymorphic microsatellite loci in animal species of commercial or conservational value. The purpose of those studies was to enable the individualization of specific animals [10], and as a result several genotyping kits are commercially available today. Our interest was to determine whether human trace DNA could be recovered in sufficient amount for further genotyping and individualization. When handling trace evidence, it is of utmost importance to extract all available DNA and remove all possible inhibitors that would adversely affect the amplification process. Two methods were examined for that purpose, an inorganic extraction method involving a chelating reagent (Chelex ${ }^{\circledR} 100$ resin) [11] and a method that involves an additional step of DNA purification with the use of magnetic beads and elution buffers (EZ1 ${ }^{\circledR}$ DNA Investigator Kit). EZ1 ${ }^{\circledR}$ showed a clear advantage over Chelex, as it was able to reproduce two full donor profiles and four in which a single allele was missing from a full donor profile. A detailed analysis of the obtained electropherograms showed fewer instances of allelic drop-out and a good heterozygote allele peak balance within and between loci when $\mathrm{EZ} 1^{\circledR}$ kit was used. Poorer results obtained through the use of the Chelex ${ }^{\circledR} 100$ method could be due to the absence of a purification step incorporated into the EZ1 ${ }^{\circledR}$ protocol, especially considering that the Chelex resin itself is a potential PCR inhibitor. Other influencing factors might be the alkaline environment in which the Chelex procedure takes place, as well as the elevated temperature required for denaturation of DNA and the inactivation of proteinase K. It might be of future interest for trace DNA processing to contrast both methods against other automated DNA extraction techniques, since recent studies have described losses during sample collection and DNA extraction of up to $75 \%$ when manual extraction methods were used [12].

In reference to trace forensic samples, the efficiency of sample collection is of paramount importance, for evidence not collected is often irrevocably lost. Trace DNA samples are collected primarily through the use of cotton swabs, moistened with ultrafiltered water, but dry swabbing of a sample area may also be used. In our study we aimed to determine which method of sample collection could best be used for recovery of trace epithelial cells from animal hairs. The wet swab method of sample collection garnered better locus profiles with dog hair samples, while the dry swab method had greater success with sheep hair samples, if only marginally. The difference in obtained results may be possible to explain due to differing surface characteristics of the hairs. Another possible explanation could be derived from different coating of the surface of hairs in question, derived from sebaceous and sweat glands found in the dermis, which could adversely affect the retention of epithelial cells on the hair surface as well as their collection.

In conclusion, our preliminary findings show that the EZ1 ${ }^{\circledR}$ DNA Investigator Kit has better results with DNA extraction from trace epithelial cells obtained from animal 
hair samples. We also showed differences in results linked to the method of sample collection, however further research is needed to determine the underlying causes. A double swab technique has been recommended in the recent years, and is claimed to improve DNA retrieval [13]. The use of other automated DNA extraction methods and devices should also be investigated, since they require less specimen handling and often offer purification protocols. The quality of obtained DNA profiles also varied intraspecifically, which is most likely linked to differences in hair morphology and composition, although further research is likewise needed in that area. Because animals are ever present in human daily lives, they can often be very informative in the course of forensic examinations. Therefore, introduction of novel methods of collecting forensic evidence from animals can only benefit the course of a forensic investigation, and positively influence its outcome.

\section{Acknowledgements}

This study was funded by the Ministry of Interior of Croatia. The authors thank Siniša Merkaš and Adela Makar for technical support.

\section{Authors' contributions}

MR, ML and MJ carried out sample processing and DNA analysis. IS and DS participated in the design of the study and were in charge of light and electron microscopy of hair samples and image processing. JC and ZZS participated in the study design, coordination, and manuscript drafting. BS, MP and GM conceived of the study, assisted with data analysis and manuscript drafting. All authors read and approved the final manuscript.

\section{Declaration of conflicting interests}

The author(s) declared no potential conflicts of interest with respect to the research, authorship, and/or publication of this article.

\section{REFERENCES}

1. Roewer L: DNA fingerprinting in forensics: past, present, future. Investig Genet 2013, 4:22.

2. Merck MD: Special considerations in animal cruelty cases. In: Veterinary Forensics: Animal cruelty investigations. Ames, Iowa, USA: Blackwell Publishing; 2007, 59-78.

3. Brauner P, Reshef A, Gorski A: DNA profiling of trace evidence - Mitigating evidence in a dog biting case. J Forensic Sci 2001, 46:1232-1234. 
4. Merck MD: Animal fighting. In: Veterinary Forensics: Animal cruelty investigations. Ames, Iowa, USA: Blackwell Publishing; 2007, 235-240.

5. Walsh PS, Metzger DA, Higuchi R: Chelex 100 as a medium for simple extraction of DNA for PCR-based typing from forensic material. Biotechniques 1991:506-513.

6. Stangegaard M, Jørgensen M, Hansen AJ, Morling N: Automated extraction of DNA from reference samples from various types of biological materials on the Qiagen BioRobot EZ1 workstation. Forensic Sci Int-Gen 2009, 2:69-70.

7. Saferstein R: Hairs, fibers, and paint. In: Criminalistics: An introduction to forensic science, 6th Edition. New Jersey, USA: Prentice Hall; 1998, 211-252.

8. Wickenheiser RA: Trace DNA: A review, discussion of theory, and application of the transfer of trace quantities of DNA through skin contact. J Forensic Sci 2002, 47:442-450.

9. Gršković B, Markulin D, Zidkova A, Crnjac J, Anđelinović Š, Marijanović I, Tomašević L, Popović M, Primorac D, Mršić G: Impact of donor age, gender and handling time on the DNA concentration left on different surfaces. International Journal of BioMedicine 2014, 4:169-174.

10. Jakubczak A, Jezewska G: Validation of StockMarks ${ }^{\circledR}$ set for identifying origin of species from the canine family. Med Weter 2008, 64:832-835.

11. Walsh PS, Metzger DA, Higuchi R: Chelex 100 as a medium for simple extraction of DNA for PCR-based typing from forensic material. Biotechniques 1991, 10:506-513.

12. Frégeau CJ, Lett CM, Fourney RM: Validation of a DNA IQ ${ }^{\mathrm{TM}}$-based extraction method for TECAN robotic liquid handling workstations for processing casework. Forensic Sci Int Genet 2010, 4:292-304.

13. Pang BCM, Cheung BKK: Double swab technique for collecting touched evidence. Legal Med 2007, 9:181-184.

\section{IZUZIMANJE HUMANOG DNK PROFILA SA OBRISA ŽIVOTINJSKE DLAKE}

ŠPOLJARIĆ Branimira, POPOVIĆ Maja, CRNJAC Josip, ŽDERIĆ SAVATOVIĆ Zrinka, RATKO Martina, LOZANČIĆ Mateja, JURAK Matea, ŠPOLJARIĆ Igor, ŠPOLJARIĆ Daniel, MRŠIĆ Gordan

Životinjske dlake su pogodna površina za zadržavanje tragova epitela kao forenzičkih uzoraka. Cilj ovog istraživanja je bio trostruki: procijeniti različite metode uzimanja uzoraka (vlažni i suvi obris) i ekstrakcije DNK (Chelex® 100 metoda iQiagenEZ1® DNA Investigator Kit), uporediti morfološke karakteristike vlakana dlake poreklom od dve vrste (pas, ovca) i njihov konačni učinak na uzimanje i obradu uzoraka. Preliminarni rezultati upućuju kako upotreba EZ1® DNAInvestigator Kit-a rezultira kvalitetnijim profilom DNK donora. Rezultati različitih metoda uzimanja uzoraka pokazuju unutarvrsne razlike koje zahtevaju dalje istraživanje. Sposobnost zadržavanja i kasnije 
ekstrakcije DNK tragova je slična u obe ispitane vrste, uprkos značajnim morfološkim razlikama u njihovim dlačnim pokrivačima. 